\title{
Long-term changes in the tree radial growth and intrinsic water-use efficiency of Chuanxi spruce (Picea likiangensis var. balfouriana) in southwestern China
}

\author{
WANG Yang ${ }^{1,2}$, ZHANG Yong ${ }^{1}$, FANG Ouya ${ }^{3}$, 'SHAO Xuemei ${ }^{1}$
}

1. Key Laboratory of Land Surface Pattern and Simulation, Institute of Geographic Sciences and Natural Resources Research, CAS, Beijing 100101, China;

2. University of Chinese Academy of Sciences, Beijing 100101, China;

3. State Key Laboratory of Vegetation and Environmental Change, Institute of Botany, CAS, Beijing 100093, China

\begin{abstract}
Elevated $\mathrm{CO}_{2}$ level in the atmosphere is expected to improve the tree growth rates and intrinsic water-use efficiency (iWUE). Although current results inferring from tree rings found the tree growth decline in water-limited area, it is still unclear whether spruce trees in humid southwestern China benefit from the increasing $\mathrm{CO}_{2}$. In this study, tree-ring width data were used to investigate the tree radial growth rate of Chuanxi spruce (Picea likiangensis var. balfouriana). Moreover, combining with the tree-ring carbon isotope date, we analyzed the physiological responses of Chuanxi spruce to rising $\mathrm{CO}_{2}$ concentrations in the atmosphere $\left(C_{a}\right)$ associated with climatic change in southwestern China. From 1851 to 2009, iWUE of Chuanxi spruce rose by approximately $30.4 \%$, and the ratio of atmospheric $\mathrm{CO}_{2}$ to leaf intercellular $\mathrm{CO}_{2}$ concentration $\left(\mathrm{C}_{\mathrm{i}} / \mathrm{C}_{\mathrm{a}}\right)$ showed no significant trend in the study area. The result suggested that Chuanxi spruce used an active response strategy when $C_{a}$ was significantly increased. iWUE showed a significant increasing trend in parallel with tree radial growth, indicating that the increasing iWUE resulted in an increase in radial growth. These results suggest that spruce forests in southwestern China have not shown declining trends under increasing $\mathrm{C}_{\mathrm{a}}$ and climate change scenarios, in contrast to trees growing in water-limited areas. Therefore, spruce forests benefit from the increasing $\mathrm{CO}_{2}$ in the atmosphere in the humid areas of southwestern China.
\end{abstract}

Keywords: tree ring; basel area increment; carbon isotope; intrinsic water-use efficiency; $\mathrm{CO}_{2}$ fertilization

Received: 2017-04-18 Accepted: 2017-07-05

Foundation: National Basic Research Program of China '973', No.2012CB956201; Key Program of National Natural Science Foundation of China, No.41630529

Author: Wang Yang (1984-), PhD, specialized in dendrochronology and dendroecology. E-mail: wangy.10b@igsnrr.ac.cn

"Corresponding author: Shao Xuemei (1957-), Professor, specialized in dendrochronology and dendroclimatology. E-mail: shaoxm@igsnrr.ac.cn 


\section{Introduction}

Atmospheric $\mathrm{CO}_{2}$ concentrations $\left(\mathrm{C}_{\mathrm{a}}\right)$ have been rising at an unprecedented rate since the industrial revolution and are now greater than 390 ppm (IPCC, 2013). Increased $C_{a}$ and associated with climate change are expected to improve the intrinsic water-use efficiency (iWUE) levels of trees, which is a useful physical indicator of the carbon assimilated in the leaf transpiration process (Ehleringer and Cerling, 1995; Norby and Zak, 2011; Kallarackal and Roby, 2012). As iWUE improved, the tree growth usually increased and its ability for carbon sequestration will enhance (Fang et al., 2001; Morén et al., 2001). According to simulations based on empirical analysis, additional increases in $\mathrm{C}_{\mathrm{a}}$ will largely improve the iWUE in different forest types by the end of the 21 st century (Huang et al., 2007). However, we know little about the effects of increasing $C_{a}$ and associated with global change on natural tree growth in different regions on a long time scale (Liu et al., 2014) owing to lack of long-term observational data.

Stable carbon compositions $\left(\delta^{13} \mathrm{C}\right)$ in tree rings have been recommended as a useful tool for understanding past environment conditions and how plants respond to environmental change (Hietz et al., 2005; Linares et al., 2009). Previous studies have used tree ring $\delta^{13} \mathrm{C}$ to analyze how trees respond to climate change and increasing $\mathrm{C}_{\mathrm{a}}$ in nature condition (Loader et al., 2008; Nock et al., 2011; Liu et al., 2014). Their results show that the responses are region-dependent, suggesting that trees use different adaptation strategies in response to environmental change. Increasing iWUE levels do not always enhance tree radial growth rates due to the interaction with different growth conditions and tree species (Newberry, 2010; Andreu-hayles et al., 2011; Gyenge et al., 2012; Silva et al., 2013; Brito et al., 2016). In China, studies have been performed in water-limited area (Wang et al., 2012; Xu et al., 2013; Wu et al., 2015), and their results show that the tree radial growth rates do not accelerate when iWUE increases significantly. However, the effects on trees growing in humid locations are not fully understood. Although some studies were carried out in humid area of China (Silva et al., 2016; Huang et al., 2017; Li et al., 2017), more research is needed to gain more knowledge on how different tree species growing in different environmental conditions respond to increasing $\mathrm{C}_{\mathrm{a}}$ and climate change.

In southwestern China, Chuanxi spruce (Picea balfouriana) plays a key role in environmental protection and wood production (Li et al., 2014). It is crucial to evaluate how spruce trees respond to $C_{a}$ increases and to climate change. In our study, long-term records of basal area increments (BAI) and iWUE were developed for Chuanxi spruce based on tree-ring width data and $\delta^{13} \mathrm{C}$ data, respectively. Further, we analyzed the tree growth rates and gas exchange responses to both rising $\mathrm{C}_{\mathrm{a}}$ levels and changing climatic patterns. Our objectives were (1) to understand how BAI and iWUE have changed with increasing $\mathrm{C}_{\mathrm{a}}$ levels and climatic changes from 1851 to 2009; (2) to determine the relationship between iWUE and BAI; and (3) to discuss how trees physiologically respond to increasing $C_{a}$.

\section{Materials and methods}

\subsection{Description of the study site}

The study site was located in the town of Jinchuan in Sichuan Province of Southwest China $\left(101^{\circ} 42^{\prime} \mathrm{E}, 31^{\circ} 31^{\prime} \mathrm{N}\right)$. This area is located in Southwest China's plateau area, and it is close 
to the Tibetan Plateau (Figure 1). The elevation exceeds $3500 \mathrm{~m}$. The rainy season runs from May to September, and annual precipitation levels range from $500 \mathrm{~mm}$ to approximately 800 $\mathrm{mm}$. June is the wettest month, and December is the driest. The annual mean temperature is $12.5^{\circ} \mathrm{C}$. January is the coldest month, and July is the hottest month (Figure 2). The climate data used in this study was obtained from the Jinchuan Meteorological Station $\left(102^{\circ} 0^{\prime} \mathrm{E}\right.$, $\left.31^{\circ} 30^{\prime} \mathrm{N}\right)$. From 1961 to 2008 , temperatures in this area did not show any increasing trend and annual precipitation increased slightly (by approximately $3.73 \mathrm{~mm}$ per year, Figure 3 ).

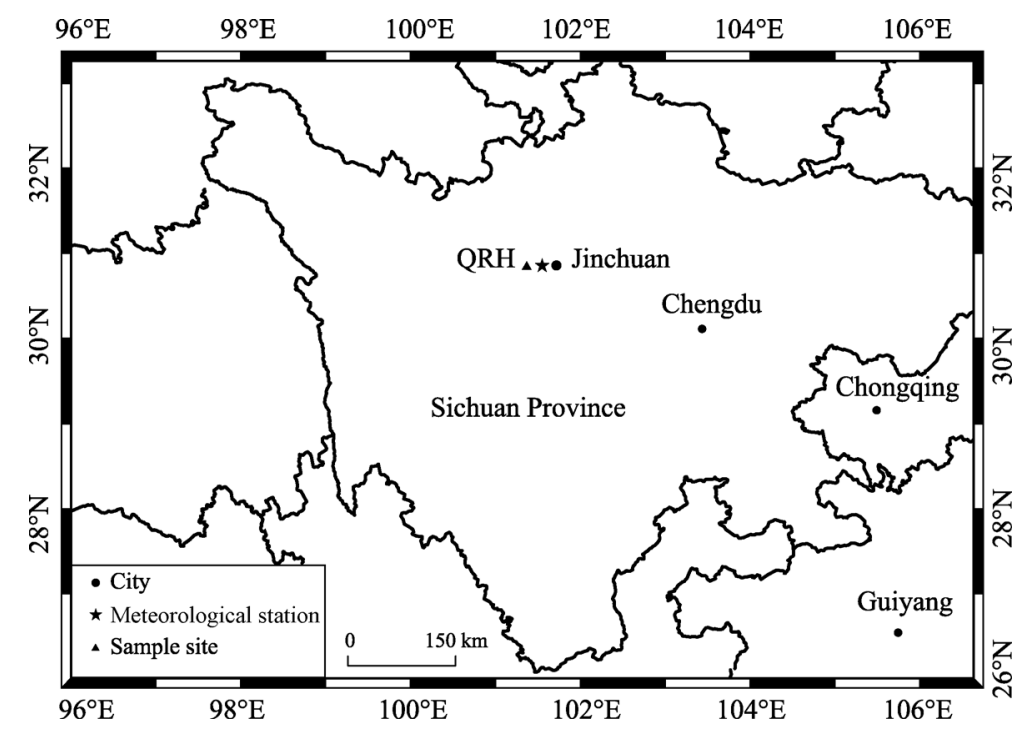

Figure 1 Location of the sample site and meteorological station

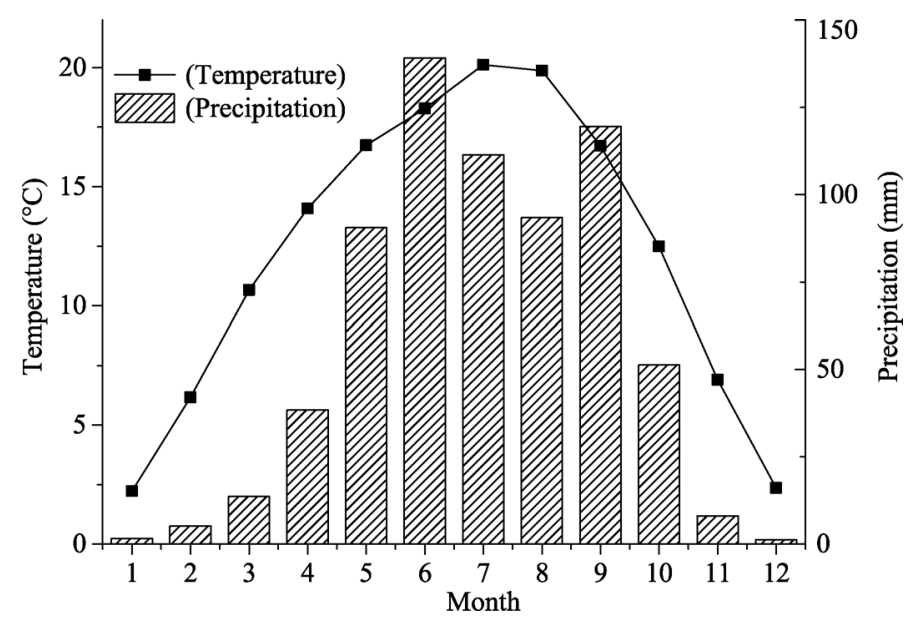

Figure 2 Mean monthly temperatures and precipitation at the Jinchuan Meteorological Station from 1960 to 2008

\subsection{Tree ring sampling and analysis}

We sampled 56 increment cores from 25 healthy spruce trees (two or three cores per tree) in total using a 10-mm-diameter increment borer. The increment cores were treated by standard dendrochronological procedures at the tree ring lab. The tree-ring width was measured using the Lintab-6 platform. The resolution of the measurement was $0.01 \mathrm{~mm}$. The COFECHA 
program was used to check the accuracy of the tree-ring width measurements and cross-dated results (Holmes, 1983). Then, the ARSTAN program was used to build the standard tree ring width chronology (Cook and Holmes, 1986). The negative exponential and linear regression curves were used to detrend the tree-ring width data. To evaluate long-term tree growth trends, we converted the tree-ring width data into BAI using equation 1 below:

$$
\mathrm{BAI}=\pi \times\left(R_{n}^{2}-R_{n-1}^{2}\right)
$$

where $R$ refers to the radius of a tree in a given year and $n$ refers to the year that the ring formed (West, 1980; Johnson and Abrams, 2009).

\section{$2.3 \alpha$-Cellulose extraction and isotope analysis}

After cross-dating, eight increment cores with no obvious signs of damage from different trees were chosen for isotope analysis. We carefully split the increment cores at a one-year resolution by using

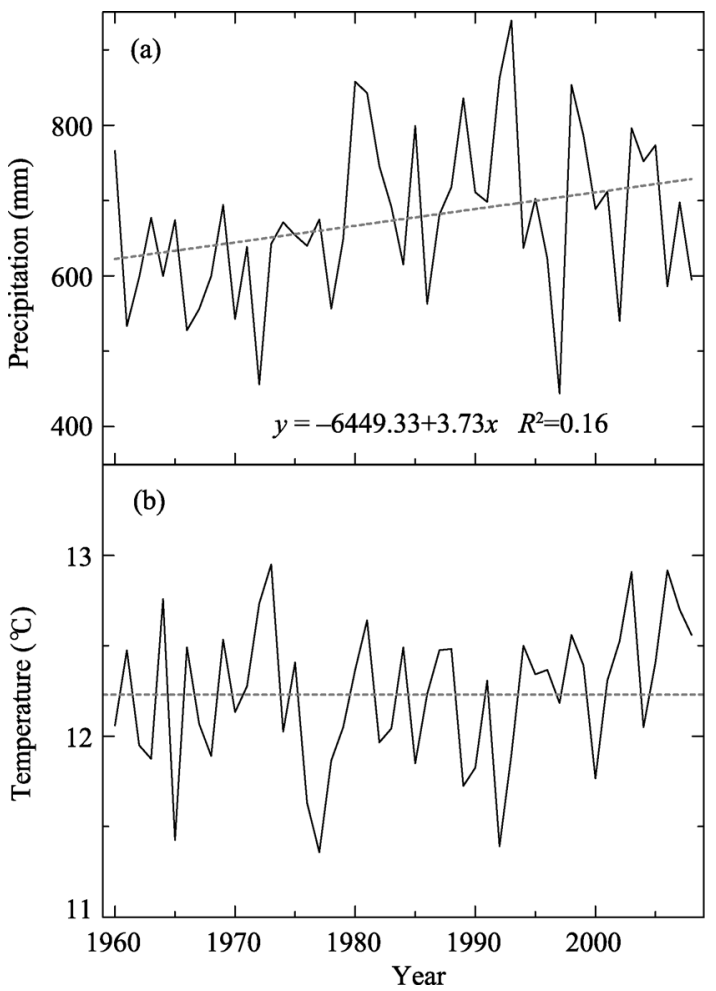

Figure 3 Trends in annual total precipitation (a) and annual mean temperature (b) from 1960 to 2008. The grey dash line is the result of the linear regression of precipitation. knife blades under a microscope. The split rings of the same year were pooled together prior to $\alpha$-cellulose extraction. The $\alpha$-cellulose of tree rings was extracted in a standard method (Green, 1963; Loader et al., 1997). An elemental analyzer coupled with an isotope mass spectrometer was used to measure the tree-ring $\delta^{13} \mathrm{C}$ values. This process was carried out at the state key laboratory of vegetation and environmental change, Institute of Botany, the Chinese Academy of Science. The results were expressed as a ratio of tree ring samples to the Vienna Pee Dee Belemnite (VPDB) standard (Coplen, 1995). The standard deviation of the analysis was less than $0.3 \%$. iWUE values of Chuanxi spruce were calculated by the Farquhar' method:

$$
\mathrm{iWUE}=\mathrm{A} / \mathrm{g}=\left(\mathrm{C}_{\mathrm{a}}-\mathrm{C}_{\mathrm{i}}\right) / 1.6
$$

where $\mathrm{A}$ is the photosynthetic assimilation rate and $\mathrm{g}$ is the stomatal conductance (Ehleringer et al., 1993). The $\mathrm{C}_{\mathrm{i}}$ values were determined using the equation from Francey and Farquhar (1982):

$$
\left.\mathrm{C}_{\mathrm{i}}=\left(\delta^{13} \mathrm{C}_{\mathrm{a}}-\delta^{13} \mathrm{C}_{\mathrm{p}}\right) /\left(1+\delta^{13} \mathrm{C}_{\mathrm{p}} / 1000\right)-\mathrm{a}\right] * \mathrm{C}_{\mathrm{a}} /(\mathrm{b}-\mathrm{a})
$$

where $\delta^{13} \mathrm{Ca}$ is the $\delta^{13} \mathrm{C}$ value of ambient air and $\delta^{13} \mathrm{C}_{\mathrm{p}}$ is the $\delta^{13} \mathrm{C}$ value of the tree-ring a-cellulose. The parameters a (4.4\%o) and b (27\%o) were considered constant (a was the isotopic discrimination when $\mathrm{CO}_{2}$ diffused from the atmosphere into the intercellular space of cells; b was the isotopic discrimination caused by discrimination of RuBP carboxylase against $\mathrm{CO}_{2}$ ). 
Saurer et al. (2004) presented three scenarios to explain how plants respond to increasing $\mathrm{CO}_{2}$ : (1) $\mathrm{C}_{\mathrm{i}}$ remains constant and iWUE significantly increases, (2) $\mathrm{C}_{\mathrm{i}} / \mathrm{C}_{\mathrm{a}}$ remains constant and iWUE slightly increases, (3) both $\mathrm{C}_{\mathrm{a}}-\mathrm{C}_{\mathrm{i}}$ and iWUE remain constant. In this study, we use Saurer's method to evaluate how trees physiologically respond to increasing $C_{a}$.

\section{Results}

\subsection{The trends of tree-ring width, BAI and tree-ring $\delta^{13} \mathrm{C}$}

Overall, the Chuanxi spruce tree-ring width exhibited a clearly increasing trend over the period of 1851-2009 (Figure 4). During the early phases of the study period (1851-1900), the tree-ring width showed a relatively flat phase followed by a continuously increasing phase until 1950. During the last portion of our study period (1951-2009), the tree-ring width data increased steadily, reaching values greater than the long-term mean. The BAI levels followed a similar trend as the tree-ring width. From 1851-1900, the BAI levels did not significantly change, with a mean value of $6.97 \mathrm{~cm}^{2} \cdot \mathrm{year}^{-1}$. Then, the BAI levels rapidly increased from 1901 to 1950 , reaching a peak value of $10.4 \mathrm{~cm}^{2} \cdot$ year $^{-1}$ in 1933 . After 1951, the BAI increased slightly, and its mean value reached peak level during the study period (1851-2009).
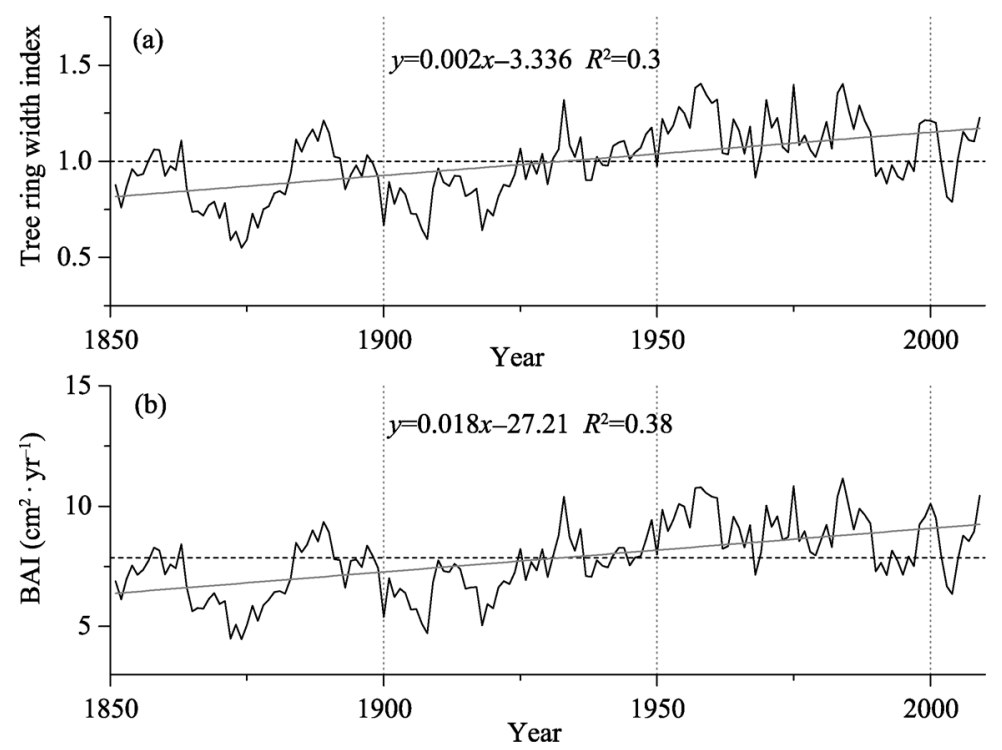

Figure 4 Trends of the tree-ring width (a) and basal area increment (BAI) (b) for Chuanxi spruce from 1851 to 2009. Horizontal lines represent the mean value for the study period. The grey line is the result of the linear regression of BAI.

The raw $\delta^{13} \mathrm{C}$ value for Chuanxi spruce decreased significantly from 1851 to 2009, with a mean value of $-22.87 \%$. The $\delta^{13} \mathrm{C}$ changes from 1851 to 1950 were minor, ranging from -21.048 to -23.043 at a decreasing rate of $0.02 \%$ per year. After 1950 , trees had accelerated rates of $\delta^{13} \mathrm{C}$ decline, reaching $0.04 \%$ per year, with the lowest value of $-24.176 \%$ in 2008 . These decreasing $\delta^{13} \mathrm{C}$ trends reflected changes in atmospheric $\delta^{13} \mathrm{C}$. The raw $\delta^{13} \mathrm{C}$ values for Chuanxi spruce had more negative values after 1850 because more isotopically depleted $\mathrm{CO}_{2}$ was released into the atmosphere after the industrial revolution. It is necessary to re- 
move this effect when using our $\delta^{13} \mathrm{C}$ series to extract climatic signals. To correct the raw $\delta^{13} \mathrm{C}$ values, we used a method presented in a previous study (McCarroll and Loader, 2004). After removing the atmospheric $\delta^{13} \mathrm{C}$ trends, the corrected series was smooth, with a mean value of $-22.16 \%$ (Figure 5).

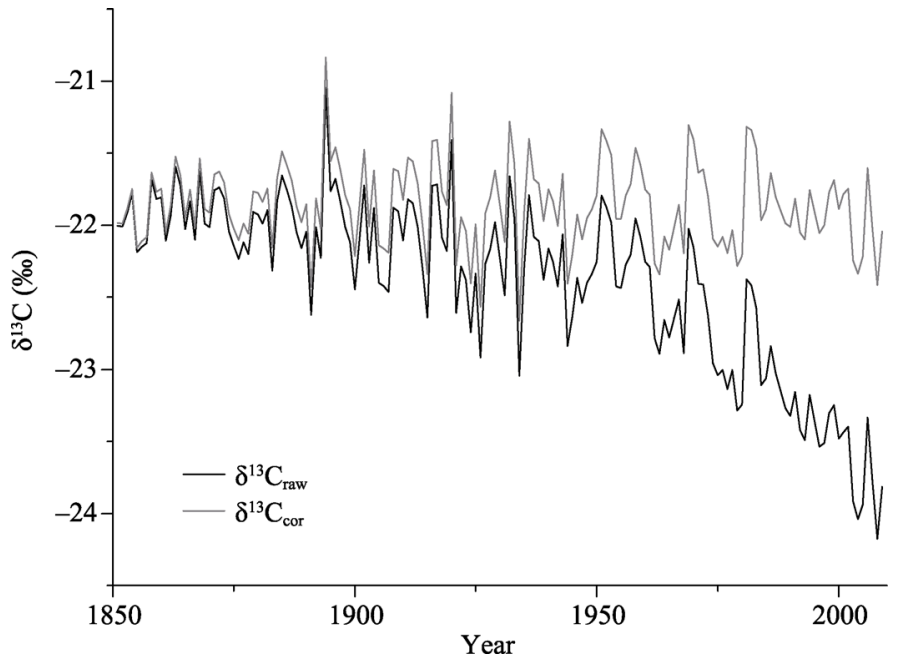

Figure 5 The raw $\left(\delta^{13} \mathrm{C}_{\text {raw }}\right)$ and corrected $\left(\delta^{13} \mathrm{C}_{\text {cor }}\right)$ chronologies for Chuanxi spruce from 1851 to 2009

\subsection{Climate correlation analysis}

Based on the results of correlation analysis, the temperature in June presented significantly positive correlations with tree-ring width $(r=0.495, p<0.01)$ and BAI $(r=0.542, p<0.01)$, although the level of tree-ring width was slightly lower than BAI's (Figures 6a and 6b). Meanwhile, correlations between precipitation and tree-ring width and BAI were very weak; none of these values reached significant levels.

Comparing with the climatic response of tree-ring width and BAI, the climatic response of the corrected $\delta^{13} \mathrm{C}\left(\delta^{13} \mathrm{C}_{\text {cor }}\right)$ showed a different pattern. We found tree-ring $\delta^{13} \mathrm{C}_{\text {cor values }}$ presented a significantly positive correlation with temperature from June to August (Figure 6c). The temperature in February of the current year also showed a strong relationship with the $\delta^{13} \mathrm{C}_{\text {cor }}$ series. We also found a negative but non-significant correlation between the precipitant and $\delta^{13} \mathrm{C}_{\text {cor }}$ series for the growing season of the current year.

\subsection{Long-term $C_{i}, C_{i} / C_{a}, C_{a}-C_{i}$ and iWUE trends}

The $C_{i}$, iWUE, $C_{i} / C_{a}$, and $C_{a}-C_{i}$ variations for the study period (1851-2009), which were inferred from tree-ring carbon isotopes, are shown in Figure 7. The $\mathrm{C}_{\mathrm{i}}$ increased significantly from 1851 to 2009 and increased faster in recent years (from 1951 to 2009). $C_{a}-C_{i}$ also showed a strong increasing trend from 1851 to 2009 (slope $=0.25, P<0.001$ ). During the early phases of the study period (1851-1900), $C_{i}$ did not have an increasing or decreasing trend. However, $\mathrm{C}_{\mathrm{i}}$ showed a clear increasing trend (slope $=0.23, P<0.001$ ) after the $1900 \mathrm{~s}$. Both $\mathrm{C}_{\mathrm{i}} / \mathrm{C}_{\mathrm{a}}$ and $\mathrm{C}_{\mathrm{a}}-\mathrm{C}_{\mathrm{i}}$ changed very slowly during the first 50 years of the study period (1851-1900), and $C_{i} / C_{a}$ remained almost stable. However, the $C_{a}-C_{i}$ levels changed faster than the $\mathrm{C}_{\mathrm{i}} / \mathrm{C}_{\mathrm{a}}$ levels, which generated a slope of approximately $0.45(p<0.001)$. The 

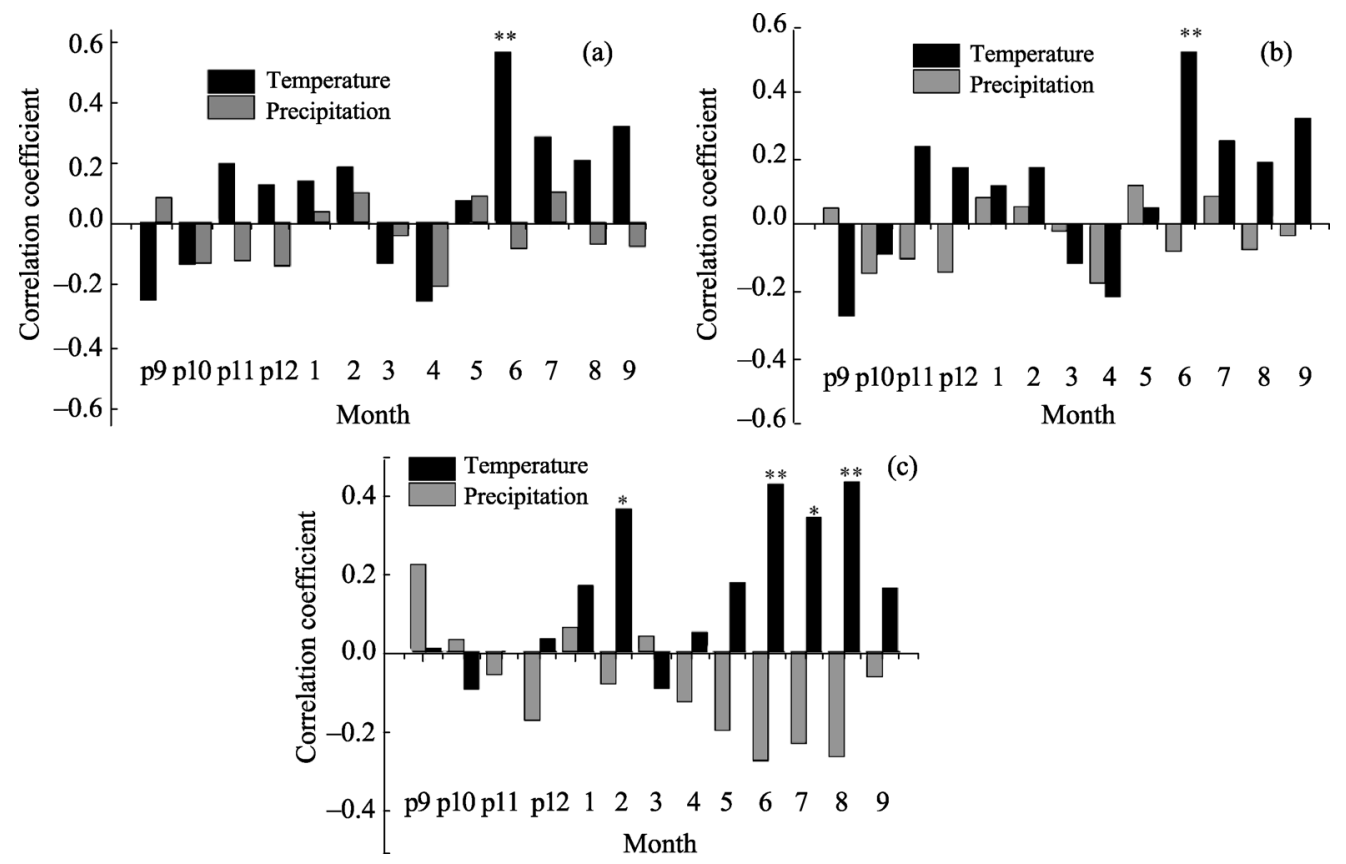

Figure 6 Correlations between tree-ring width (a), BAI (b), $\delta^{13} \mathrm{C}_{\text {cor }}(\mathrm{c})$ and climate factors from 1960-2008. $p$ indicates the previous year. Significant levels are shown above the bars: $* P<0.05$ and ${ }^{* *} P<0.01$.

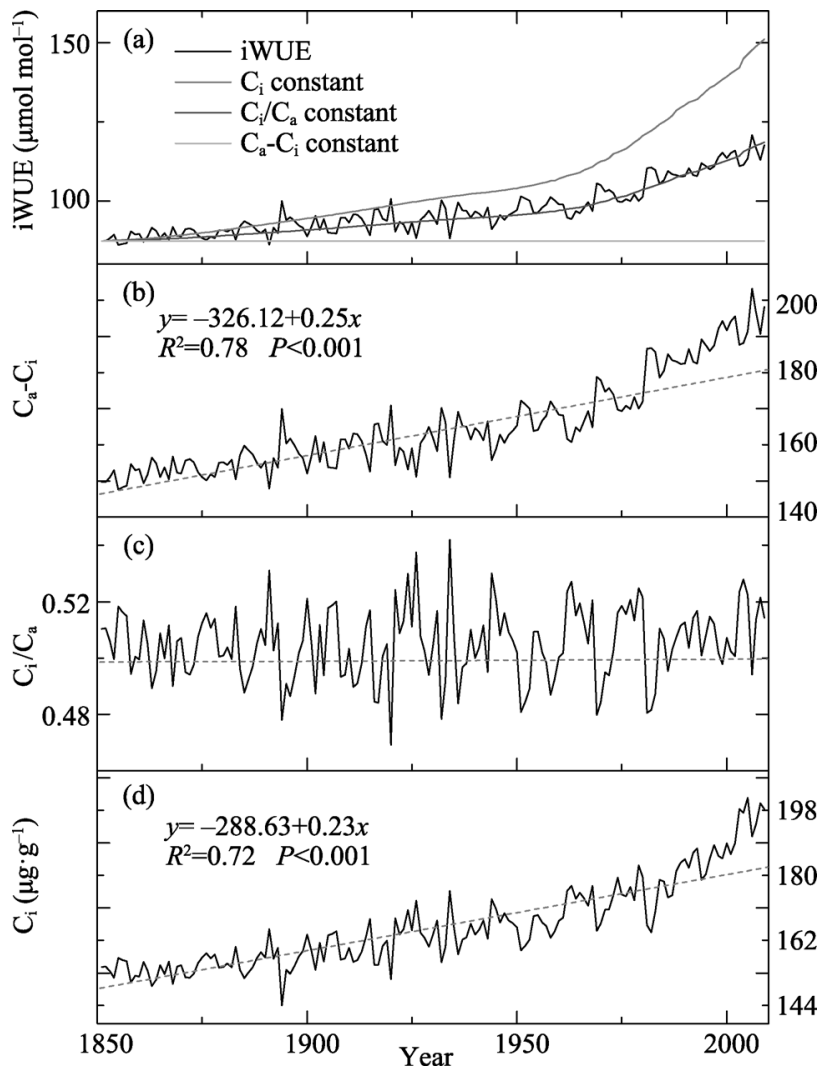

Figure 7 Trends in iWUE (a), $C_{a}-C_{i}(b), C_{i} / C_{a}(c)$ and $C_{i}(d)$ for Chuanxi spruce from 1851 to 2009 . The grey dash lines are the results of linear regression. iWUE in different scenarios was shown in (a). 
$\mathrm{C}_{\mathrm{i}} / \mathrm{C}_{\mathrm{a}}$ levels remained relatively constant. Overall, throughout the study period, $\mathrm{C}_{\mathrm{a}}-\mathrm{C}_{\mathrm{i}}$ and $\mathrm{C}_{\mathrm{i}}$ followed a significantly increasing trend, but $\mathrm{C}_{\mathrm{i}} / \mathrm{C}_{\mathrm{a}}$ remained almost stable.

The iWUE for Chuanxi spruce increased from 1851 to 2009. From 1851 to 1950, iWUE did not change rapidly (slope $=0.02, p<0.001$ ). After 1950, iWUE increased faster than it did over the previous 100 years, with a slope of $1.3(p<0.001)$. iWUE reached a peak value of $120.75 \mu \mathrm{mol} \mathrm{mol}^{-1}$ in 2006. Compared with the mean value of iWUE from 1851 to 1950 , it increased by approximately $30.4 \%$.

\section{Discussion}

\subsection{The climatic information recorded in the tree-ring width and $\delta^{13} \mathrm{C}$ data}

The significantly positive effects of June temperatures on tree-ring width and BAI indicate that summer temperatures should control the growth rate of Chuanxi spruce. Meanwhile, the weak effect of precipitation on the tree-ring width, BAI and $\delta^{13} \mathrm{C}$ show that water is not as important as temperature in controlling tree radial growth. This difference is attributed to the fact that our study site is located in humid region, where annual precipitation levels reach nearly $800 \mathrm{~mm}$. In addition, our study site is situated at a high elevation. Temperature should be an important factor controlling tree growth rates. Similar results were found on Western Sichuan Plateau (Duan et al., 2010; Li et al., 2014). Since tree growth was not limited by water condition, higher mean summer temperature could contribute to tree growth by stimulating photosynthesis.

From the results of correlation analysis, we found that tree-ring $\delta^{13} \mathrm{C}$ value was dominated by the growing season temperatures (from July to August). Because carbon isotope discrimination is controlled by photosynthesis and leaf stomatal conductance, the most important climatic controls for $\delta^{13} \mathrm{C}$ values influence these physiological processes (McCarroll and Loader, 2004; Saurer et al., 2004). Our study site positioned along an upper tree line, where temperature was an important factor affecting tree growth. Overall, the radial growth rate of Chuanxi spruce and its carbon isotope discrimination were controlled by temperature during the growing season in this study area (Ferrio and Voltas, 2005; Leavitt, 2010; Loader et al., 2013).

\section{2 iWUE trends and their physiological implications}

In recent decades, several studies were performed to investigate the long-term changes in iWUE in different regions. Most of the results showed that iWUE increased significantly, especially in recent years. Peñuelas et al. (2011) found that iWUE increased by approximately $20.5 \%$ worldwide. In tropical areas, Brienen et al. (2011) found that the iWUE increased by approximately $40 \%$. In temperate areas, previous results show that iWUE increased from $19 \%$ to $48 \%$ among different tree species (Feng, 1999; Waterhouse et al., 2004). Frank et al. (2015) found that iWUE increased approximately $22 \%$ in Europe. According to our study, the iWUE values of Chuanxi spruce increased by $30.4 \%$ over the last 50 years, which generally agrees with the results in temperate areas. However, the increase found in our study is higher than the global average and the European average and lower than that of tropical areas. 
The increasing $\mathrm{C}_{\mathrm{a}}$ is the main cause of the strong increasing iWUE trends. Our regression analyses showed that increasing atmospheric $\mathrm{C}_{\mathrm{a}}$ levels can explain $89.8 \%$ of the observed variation in iWUE (Figure 8). This result makes sense because the theoretical model that we used to calculate the iWUE (Ehleringer et al., 1993) was significantly affected by the concentration of $\mathrm{CO}_{2}$ (Silva and Horwath, 2013). Moreover, rising $\mathrm{C}_{\mathrm{a}}$ limits leaf stomatal conductance but stimulates the photosynthesis of leaves, which may stimulate the iWUE of trees.

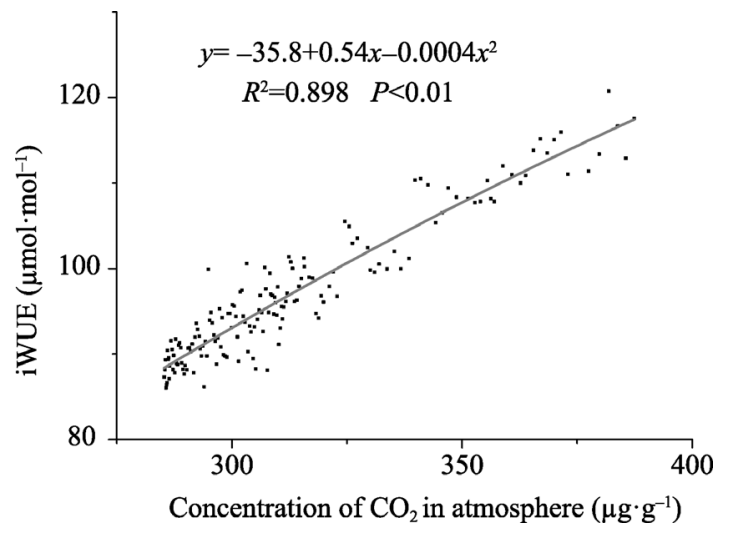

Figure 8 Scatterplot of the annual values of iWUE versus $\mathrm{C}_{\mathrm{a}}$ and the regression analysis results (grey line) FACE and open-top chamber experiments confirmed these physiological processes in trees (Eamus et al., 1993; Ainsworth and Rogers, 2007). Temporal variations in $C_{i}$ and $C_{i} / C_{a}$ may help us to know the response of spruce trees to increasing $\mathrm{C}_{\mathrm{a}}$ and how their physiological processes have changed. For our study site, the $\mathrm{C}_{\mathrm{i}} / \mathrm{C}_{\mathrm{a}}$ slope did not show any significant change, but both $\mathrm{C}_{\mathrm{i}}$ and $\mathrm{C}_{\mathrm{a}}-\mathrm{C}_{\mathrm{i}}$ showed a significant increasing trend. Based on the hypothesis of Saurer et al. (2004), our result was similar to scenario 2 (Figure 7 a). This scenario was the most common result of tree-ring carbon isotope analysis around the world (Feng, 1999). Constant $C_{i} / C_{a}$ levels reflect proportional regulation of $\mathrm{A}$ and $\mathrm{g}$ in Chuanxi spruce. It also indicated that trees have already adapted to increased $\mathrm{C}_{\mathrm{a}}$. Trees should also have decreased leave stomatal conductance, and the photosynthetic rates of trees should also decrease. (Saurer et al., 2004).

\subsection{The relationship between iWUE and BAI}

Generally, forests should theoretically show an increasing growth trend as $\mathrm{C}_{\mathrm{a}}$ continues to rise (Bazzaz, 1990; Knapp et al., 2001). Increased $C_{a}$ may directly stimulate photosynthesis through increased the RuBisCo enzyme's reaction rate. Moreover, reduced $\mathrm{CO}_{2}$ requirements decrease stomatal conductance thereby increasing iWUE (Turnbull et al., 2001; Huang et al., 2007). This phenomenon has been found in controlled experiments (e.g., FACE and open-top chamber experiments). However, in recent decades, several studies have found that forests growing in arid and semi-arid areas did not exhibit $\mathrm{CO}_{2}$ fertilization effects. These studies attribute the decline in tree growth to more severe drought effects (Silva et al., 2010; Wang et al., 2012). Few reports have been conducted on humid areas in China. According to our results, increasing $\mathrm{CO}_{2}$ levels are the main cause of the increased iWUE levels among Chuanxi spruce trees (Figure 8). The regression analysis between iWUE and BAI (Figure 9a) shows a strong positive relationship $\left(\mathrm{r}^{2}=0.38, \mathrm{p}<0.05\right)$. For the first-difference data of iWUE and BAI (Figure 9b), they also have a positively relationship $\left(\mathrm{r}^{2}=0.06\right.$, $\mathrm{p}<0.05$ ). iWUE can explain $32 \%$ of BAI variation. Increasing iWUE levels may accelerate tree radial growth, and the trees can benefit from the rising $\mathrm{CO}_{2}$ levels, which indicates that the $\mathrm{CO}_{2}$ fertilization effect exists in the humid areas of southwestern China. 

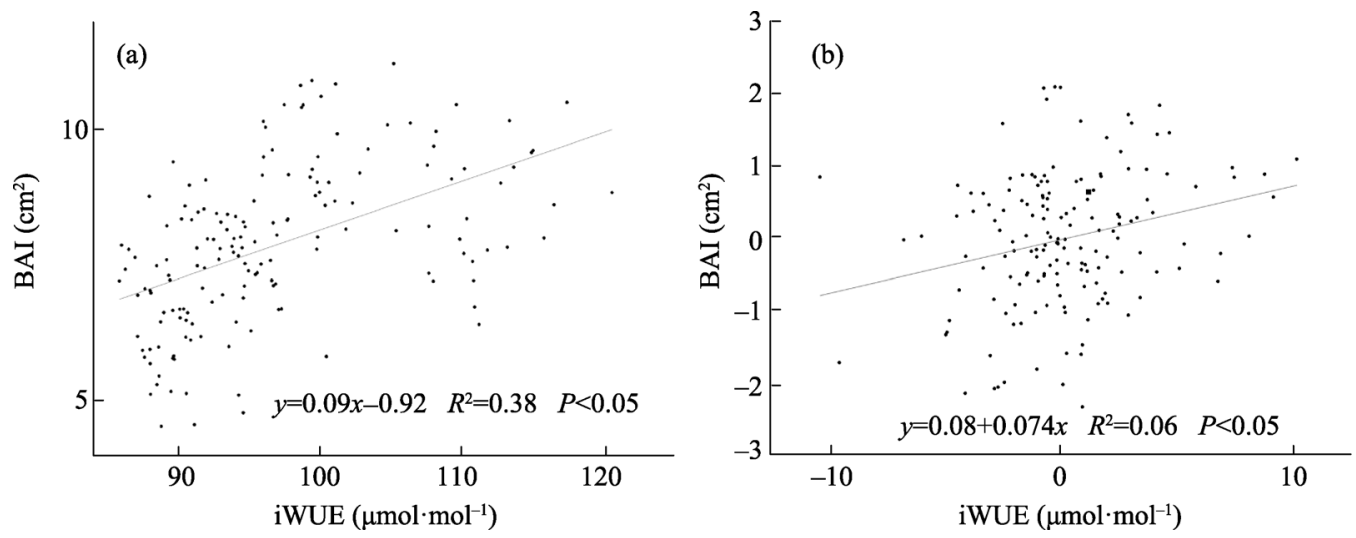

Figure 9 The relationship between BAI and iWUE for 1851-2009. (a) raw values; (b) first-difference values

\section{Conclusion}

In this study, annual-resolution $\delta^{13} \mathrm{C}$ and $\mathrm{BAI}$ chronologies were built for a temperate forest in southwestern China. The $\delta^{13} \mathrm{C}$ chronology responses to climatic variations showed that the $\delta^{13} \mathrm{C}$ was controlled by the current growing season temperature. Our results indicated that as $\mathrm{C}_{\mathrm{a}}$ increased significantly, $\mathrm{C}_{\mathrm{i}} / \mathrm{C}_{\mathrm{a}}$ remained constant, whereas $\mathrm{C}_{\mathrm{i}}$ and iWUE showed a significantly increasing trend. Chuanxi spruce trees had a positive response to rising concentrations of $\mathrm{CO}_{2}$. iWUE levels increased by $30.4 \%$ in the last 50 years. Tree radial growth occurred in parallel with increased iWUE levels, and $\mathrm{C}_{\mathrm{a}}$ was correlated with iWUE. The results showed that tree radial growth benefited from increasing $\mathrm{C}_{\mathrm{a}}$ levels through the so-called $\mathrm{CO}_{2}$ fertilization effect. The spruce trees in our study site exhibited healthy growth rates and could fix a greater amount of $\mathrm{CO}_{2}$ in the future. Our results provide useful information for the local government to develop policies for forest management in this area.

\section{Acknowledgements}

We thank Dr. Huang Lei, Dr. Chen Feng and Professor Yin Zhiyong for sampling the tree-ring cores. We thank Dr. Jinjian Li for providing the climate data. We also thank the people who provided help with our field work.

\section{References}

Ainsworth E, Rogers A, 2007. The response of photosynthesis and stomatal conductance to rising $\mathrm{CO}_{2}$ : $\mathrm{Mecha}^{-}$ nisms and environmental interactions. Plant, Cell \& Environment, 30(3): 258-270.

Alexander L, Allen S, Bindoff N et al., 2013. IPCC 2013: Summary for Policymakers. Cambridge, UK and New York, NY, USA: Cambridge University Press.

Andreu-hayles L, Planells O, Gutierrez E et al., 2011. Long tree-ring chronologies reveal 20th century increases in water-use efficiency but no enhancement of tree growth at five Iberian pine forests. Global Change Biology, 17(6): 2095-2112.

Bazzaz F A, 2003. The response of natural ecosystems to the rising global $\mathrm{CO}_{2}$ levels. Annual Review of Ecology and Systematics, 21(1): 167-196.

Brienen R, Wanek W, Hietz P, 2011. Stable carbon isotopes in tree rings indicate improved water use efficiency and drought responses of a tropical dry forest tree species. Trees, 25(1): 103-113.

Brito P, Grams T E E, Matysssek R et al., 2016. Increased water use efficiency does not prevent growth decline of 
Pinus canariensis, in a semi-arid treeline ecotone in Tenerife, Canary Islands (Spain). Annals of Forest Science, 73(3): 741-749.

Coplen T B, 1995. Discontinuance of SMOW and PDB. Nature, 375(6529): 285.

Cook E R, Holmes R L, 1986. Users manual for program ARSTAN. Palaeogeography, Palaeoclimatology, Palaeoecology, 302.

Duan J P, Wang L L, Li L et al., 2010. Temperature variability since A.D. 1837 inferred from tree-ring maximum density of Abies fabri, on Gongga Mountain, China. Science Bulletin, 55(26): 3015-3022.

Eamus D, Berryman C A, Duff G A, 1993. Assimilation, stomatal conductance, specific leaf area and chlorophyll responses to elevated $\mathrm{CO}_{2}$ of Maranthes corymbosa, a tropical monsoon rain forest species. Functional Plant Biology, 20(6): 741-755.

Ehleringer J R, Cerling T E, 1995. Atmospheric $\mathrm{CO}_{2}$ and the ratio of intercellular to ambient $\mathrm{CO}_{2}$ concentrations in plants. Tree Physiology, 15(2): 105-111.

Ehleringer J R, Hall A E, Farquhar G D, 1993. Stable isotopes and plant carbon-water relations. Stable Isotopes and Plant Carbon-water Relations, 7: 541-555.

Fang J Y, Chen A P, Peng C H et al., 2001. Changes in forest biomass carbon storage in China between 1949 and 1998. Science, 292(5525): 2320-2322.

Feng X H, 1999. Trends in intrinsic water-use efficiency of natural trees for the past 100-200 years: A response to atmospheric $\mathrm{CO}_{2}$ concentration. Geochimica et Cosmochimica Acta, 63(13): 1891-1903.

Ferrio J P, Voltas J, 2005. Carbon and oxygen isotope ratios in wood constituents of Pinus halepensis as indicators of precipitation, temperature and vapour pressure deficit. Tellus B, 57(2): 164-173.

Francey R J, Farquhar G D, 1982. An explanation of ${ }^{13} \mathrm{C} /{ }^{12} \mathrm{C}$ variations in tree rings. Nature, 297(5861): $28-31$.

Frank D C, Poulter B, Saurer M et al., 2015. Water-use efficiency and transpiration across European forests during the Anthropocene. Nature Climate Change, 5(5): 579-583.

Green J W, 1963. Wood Cellulose in Methods in Carbohydrate Chemistry. New York: Academic Press.

Gyenge J, Fernández M E, Varela S, 2012. Short- and long-term responses to seasonal drought in ponderosa pines growing at different plantation densities in Patagonia, South America. Trees, 26(6): 1905-1917.

Hietz P, Wanek W, Dünisch O, 2005. Long-term trends in cellulose $\delta^{13} \mathrm{C}$ and water-use efficiency of tropical Cedrela and Swietenia from Brazil. Tree Physiology, 25(6): 745-752.

Holmes R L, 1983. Computer-assisted quality control in tree-ring dating and measurement. Tree-ring Bulletin, 43(1): 69-78.

Huang J G, Bergeron Y, Denneler B et al., 2007. Response of forest trees to increased atmospheric $\mathrm{CO}_{2}$. Critical Reviews in Plant Sciences, 26(5/6): 265-283.

Huang R, Zhu H, Liu X et al., 2017. Does increasing intrinsic water use efficiency (iWUE) stimulate tree growth at natural alpine timberline on the southeastern Tibetan Plateau? Global and Planetary Change, 148: 217-226.

Johnson S E, Abrams M D, 2009. Basal area increment trends across age classes for two long-lived tree species in the eastern US. TRACE, 7: 127-134.

Kallarackal J, Roby T J, 2012. Responses of trees to elevated carbon dioxide and climate change. Biodiversity and Conservation, 21(5): 1327-1342.

Knapp P A, Soulé P T, Grissino M et al., 2001. Detecting potential regional effects of increased atmospheric $\mathrm{CO}_{2}$ on growth rates of western juniper. Global Change Biology, 7(8): 903-917.

Leavitt S W, 2010. Tree-ring c-h-o isotope variability and sampling. Science of The Total Environment, 408(22): 5244-5253.

Li D, Fang K, Li Y et al., 2017. Climate, intrinsic water-use efficiency and tree growth over the past 150 years in humid subtropical China. Plos One, 2017, 12(2): e0172045.

Li Q F, Zhang S G, Wang J H, 2014. Transcriptome analysis of callus from Picea balfouriana, BMC Genomics, 15(1): 553.

Li Z S, Liu G H, Gong L et al., 2015. Tree ring-based temperature reconstruction over the past 186 years for the Miyaluo Natural Reserve, western Sichuan Province of China. Theoretical and Applied Climatology, 120(3): 495-506. 
Linares J C, Delgado H A, Camarero J J et al., 2009. Competition and drought limit the response of water-use efficiency to rising atmospheric carbon dioxide in the Mediterranean fir Abies pinsapo. Oecologia, 161(3): 611-624.

Liu X H, Wang W Z, Xu G B et al., 2014. Tree growth and intrinsic water-use efficiency of inland riparian forests in northwestern China: evaluation via $\delta^{13} \mathrm{C}$ and $\delta^{18} \mathrm{O}$ analysis of tree rings. Tree Physiology, 34(6): 966-980.

Loader N J, Robertson I, Barker A C et al., 1997. An improved technique for the batch processing of small whole wood samples to $\alpha$-cellulose. Chemical Geology, 136(3): 313-317.

Loader N J, Santillo P M, Woodman-Ralph J P et al., 2008. Multiple stable isotopes from oak trees in southwestern Scotland and the potential for stable isotope dendroclimatology in maritime climatic regions. Chemical Geology, 252(1): 62-71.

Loader N J, Young G H F, McCarroll D et al., 2013. Quantifying uncertainty in isotope dendroclimatology. The Holocene, 23(9): 1221-1226.

McCarroll D, Loader N J, 2004. Stable isotopes in tree rings. Quaternary Science Reviews, 23(7): 771-801.

Newberry T L, 2010. Effect of climatic variability on $\delta^{13} \mathrm{C}$ and tree-ring growth in piñon pine (Pinus edulis). Trees, 24(3): 551-559.

Nock C A, Baker P J, Wanek W et al., 2011. Long-term increases in intrinsic water-use efficiency do not lead to increased stem growth in a tropical monsoon forest in western Thailand. Global Change Biology, 17(2): 1049-1063.

Norby R J, Zak D R, 2011. Ecological lessons from free-air $\mathrm{CO}_{2}$ enrichment (FACE) experiments. Annual Review of Ecology, Evolution, and Systematics, 42(1): 181.

Morén A S, Lindroth A, Grelle A, 2001. Water-use efficiency as a means of modelling net assimilation in boreal forests. Trees, 15(2): 67-74.

Peñuelas J, Canadell J G, Ogaya R, 2011. Increased water-use efficiency during the 20th century did not translate into enhanced tree growth. Global Ecology and Biogeography, 20(4): 597-608.

Saurer M, Siegwolf R, Schweingruber F H, 2004. Carbon isotope discrimination indicates improving water-use efficiency of trees in northern Eurasia over the last 100 years. Global Change Biology, 10(12): 2109-2120.

Silva L C R, Anand M, Leithead M D, 2010. Recent widespread tree growth decline despite increasing atmospheric $\mathrm{CO}_{2}$. Plos One, 5(7): e11543.

Silva L C R, Anand M, 2013. Probing for the influence of atmospheric $\mathrm{CO}_{2}$ and climate change on forest ecosystems across biomes. Global Ecology and Biogeography, 22(1): 83-92.

Silva L C R, Horwath W R, 2013. Explaining global increases in water use efficiency: why have we overestimated responses to rising atmospheric $\mathrm{CO}_{2}$ in natural forest ecosystems? PloS One, 8(1): e53089.

Silva L C R, Sun G, Xia Z B et al., 2016. Tree growth acceleration and expansion of alpine forests: The synergistic effect of atmospheric and edaphic change. Science Advances, 2(8): e1501302.

Turnbull M H, Whitehead D, Tissue D T et al., 2001. Responses of leaf respiration to temperature and leaf characteristics in three deciduous tree species vary with site water availability. Tree Physiology, 21(9): 571-578.

Waterhouse J S, Switsur V R, Barker A C et al., 2004. Northern European trees show a progressively diminishing response to increasing atmospheric carbon dioxide concentrations. Quaternary Science Reviews, 23(7): $803-810$.

Wang W Z, Liu X H, An W L et al., 2012. Increased intrinsic water-use efficiency during a period with persistent decreased tree radial growth in northwestern China: Causes and implications. Forest Ecology and Management, 275(1): 14-22.

West P W, 1980. Use of diameter increment and basal area increment in tree growth studies. Canadian Journal of Forest Research, 10(1): 71-77.

Wu G J, Liu X H, Chen T et al., 2015. Long-term variation of tree growth and intrinsic water-use efficiency in Schrenk spruce with increasing $\mathrm{CO}_{2}$ concentration and climate warming in the western Tianshan Mountains, China. Acta Physiologiae Plantarum, 37(8): 150.

$\mathrm{Xu}$ G B, Liu X H, Qin D H et al., 2013. Climate warming and increasing atmospheric $\mathrm{CO}_{2}$ have contributed to increased intrinsic water-use efficiency on the northeastern Tibetan Plateau since 1850. Trees, 27(2): 465-475. 